\title{
Effect of Advertising, Direct Marketing, Word of Mouth and Personal Selling on Consumer Purchasing Decisions
}

\author{
Soehardi ${ }^{1}$ \\ ${ }^{1}$ Bhayangkara Jakarta Raya University \\ Email Address: \\ soehardi@dsn.ubharajaya.ac.id
}

\begin{abstract}
The purpose of this study is to analyze the effect of advertising, direct marketing, word of mouth and personal selling on consumer purchasing decisions for passenger ship tickets in Tanjung Pasir. The population in this study are all tourists who use sea transportation services from Tanjung Pasir beach to Untung Island. The sample used is purposive sampling with 155 respondents distributed questionnaires and 82 respondents returned. Quantitative research methods are used in this study with analysis of construct validity and reliability, discriminant validity, outer loading, collinearity statistics, path coefficients, $\mathrm{R}$ square and model fit. The results obtained that there is a significant effect of advertising on consumer purchasing decisions, direct marketing on consumer purchasing decisions, word of mouth on consumer purchasing decisions and personal selling on consumer purchasing decisions.
\end{abstract}

Keywords: Advertising, Direct Marketing, Word of Mouth, Personal Selling and Consumer Purchase Decisions.

\begin{abstract}
Abstrak: Tujuan penelitian ini adalah untuk menganalisis pengaruh periklanan, pemasaran langsung, word of mouth dan personal selling terhadap keputusan pembelian konsumen tiket kapal penumpang di Tanjung Pasir. Populasi dalam penelitian ini adalah seluruh wisatawan yang menggunakan jasa transportasi laut dari pantai Tanjung Pasir menuju Pulau Untung. Sampel yang digunakan adalah purposive sampling dengan menyebarkan kuisioner kepada 155 responden dan kuisioner yang kembali berjumlah 82 responden. Metode penelitian kuantitatif digunakan dalam penelitian ini dengan analisis validitas dan reliabilitas konstruk, validitas diskriminan, outer loading, statistik kolinearitas, koefisien jalur, R square dan model fit. Hasil yang diperoleh bahwa terdapat pengaruh yang signifikan periklanan terhadap keputusan pembelian konsumen, pemasaran langsung terhadap keputusan pembelian konsumen, word of mouth terhadap keputusan pembelian konsumen dan personal selling terhadap keputusan pembelian konsumen.
\end{abstract}

Kata kunci: Periklanan, Pemasaran Langsung, Word of Mouth, Personal Selling dan Keputusan Pembelian Konsumen. 


\section{INTRODUCTION}

Tanjung Pasir Beach, Teluk Naga District, Tangerang Regency is the location for various kinds of motor boats ready to take tourists and their luggage to the tourist destinations of Untung Jawa Island and Rambut Island, Thousand Islands Regency, DKI Jakarta. This location can be reached as far as $22.5 \mathrm{~km}$ from Soekarno-Hatta International Airport and $40.8 \mathrm{~km}$ from Gambir Train Station. The availability and accessibility of land and sea transportation is one of the important factors of attraction for foreign and domestic tourists who have a marine hobby and want to travel from their place of residence to the tourist destinations of Untung Jawa Island and Rambut Island, Thousand Islands, DKI Jakarta. One of the beaches used to get to the Thousand Islands is Tanjung Pasir. Untung Jawa Island is a tourist destination that is suitable for tourists who have a hobby of swimming, snorkeling and banana boating on the beach with a light breeze. (Balai Konservasi Sumber Daya Alam DKI Jakarta, 2021) Rambut Island is a habitat for 20,000 to 24 different types of birds and shady mangrove forests. Tanjung Pasir Beach is the resting place for 15 motorboats that regularly bring foreign and domestic tourists and their belongings to the tourist destinations of Untung Jawa Island and Rambut Island for 20-30 minutes or only 6.8 to $7.4 \mathrm{~km}$ away. Untung Jawa Island and Rambut Island can be seen clearly from Tanjung Pasir beach. These 15 motorboats also provide sea transportation services on a charter basis to tourist destinations throughout the Thousand Islands with rentals between IDR 2 to 3.5 million round-trip.

Tanjung Pasir Beach is very strategic in terms of security and tourist safety because its location is next to the Tanjung Pasir Navy Post. Officers from the Sea Transportation Service, Tangerang Regency, Banten Province, checked and supervised the completeness of sailing permit documents, KM eligibility and evidence of an antigen swab test before the motorboat left for Untung Jawa Island and Rambut Island. This is to ensure that the Motor Ship is or is not in accordance with standard operating procedures for the safety and security of passengers and goods as well as safety tools such as buoys, radio communications and fire extinguishers.

The first motorboat departs at Tanjung Pasir at 8:00 am, followed by subsequent motorboats every 30 to 60 minutes until the last departure at 16:00. The delay in the departure of the Motorboat from the predetermined schedule of 10 to 30 minutes was due to passengers consisting of foreign and domestic tourists arriving late at Tanjung Pasir beach. In addition, the delay in departure is also due to the large number of passengers' luggage being loaded and there are also passengers who bring motorbikes to be transported on motorbikes. Consumers who bring motorbikes are charged a parking fee of IDR 2,000 per hour or IDR 20,000 per day. As for cars, parking fees are IDR 5,000 per hour or IDR 40,000 per day. A motor boat ticket from Tanjung Pasir to Untung Jawa Island is IDR 50,000 per person round trip. Tickets for motorbikes that want to be transported on a motorbike are subject to a tariff of Rp. 20,000 per motorbike. The price of parking tickets and motor boat tickets at Tanjung Pasir Beach is cheaper than the Kali Adem Muara Angke Pier, Muara Kamal Pier and Ancol Marina. Based on information from the Transportation Agency of DKI Jakarta and Tangerang Regency as well as the captain and crew of the ship, the outgoing passengers from Tanjung Pasir to Untung Jawa Island in 2021 amounted to 25,532 people and incoming passengers from Untung Jawa Island to Tanjung Pasir in 2021 
amounted to 25,324 people. The decrease in the number of passengers occurred from January to June 2021 due to restrictions on motor boat passengers during the COVID-19 pandemic.

Along the way from Jakarta, Tangerang City and Tangerang Regency to Tanjung Pasir Beach, no advertising promotions for Motorboat services were found with the tourist destinations of Untung Jawa Island and Rambut Island. Likewise, there are no promotional advertisements for Kapal Motor both on radio and television. Several travel and tourism service agents were so enthusiastic about promoting advertisements to tourists about motor boats from Tanjung Pasir to Untung Jawa Island and Rambut Island. Telemarketing is a part of direct marketing which is often used by the marketing manager and sales force of Kapal Motor Tanjung Pasir to offer sea transportation services to regular customers, nonpermanent customers and new customers by telephone. Telemarketing is used to communicate with customers, follow up on ticket price reservations, ship departure and arrival schedules. Person to person is part of word of mouth marketing which is often used by marketing managers and sales force of Tanjung Pasir motorboats to offer sea transportation services to regular customers, non-permanent customers and new customers through face-to-face meetings. This person-to-person meeting was held while enjoying snacks and drinking coffee while waiting for the schedule before the departure of the motorboat at the MSMEs at Tanjung Pasir Beach and Untung Jawa Island. Sales meetings and incentive programs are part of word of mouth marketing which is often used by marketing managers and sales forces of Tanjung Pasir motorboats to offer sea transportation services to regular customers, temporary customers and new customers. Location of sales meetings and incentive programs for sea transportation service offerings by marketing managers and sales force of Tanjung Pasir motorboats to regular customers, non-permanent customers and new customers. This meeting usually discusses motor boat rentals along with incentive programs to attract tourist destinations on Untung Jawa Island and Rambut Island as well as other islands throughout the Thousand Islands such as tour and travel packages, accommodation, snorkeling, diving, banana boating, wildlife viewing, trekking and sports.

This explanation is strengthened in detail by (Haryanto and Yunita, 2012) that consumer purchasing decisions are influenced by advertising, product attributes, word of mouth and customer loyalty. It is also described in more detail that advertising has a significant effect on purchasing decisions, personal selling has a significant effect on purchasing decisions. Word of mouth fan has a significant effect on purchasing decisions (Setyowahyudi, 2018). This study aims to analyze consumer purchasing decisions through advertising, direct marketing, word of mouth. Mouth and personal sales of Tanjung Pasir motor boat tickets. The results of this study are expected to be used by people who love marine tourism hobbies and also for Tanjung Pasir motorboat companies in developing similar business ventures while continuing to pay attention to competition from other companies.

\section{THEORYTICAL REVIEW}

Advertising. According to (Hawks, 2021), advertising is the act of drawing public attention to something, especially with a paid announcement. Note that the definition uses the term 'action' and does not specify that advertising is limited to print, television, Internet or other 
specific media. While emphasizing 'paid announcements', it is not mandatory. Any medium that can carry a message from an organization to a potential consumer can be used for advertising. Of course, the most popular media are television, radio, internet and print media, such as newspapers, magazines, etc. Television is popular for its wide reach, but it is also expensive. Print and radio advertising can be much cheaper than television, but reach fewer people. The Internet has become a very popular advertising medium, not only because of its reasonable costs, but because its reach is not only large, but can also be very specific.

According to (Goorevich, 2019), advertising is the process of persuading targeted consumers to take a certain action, whether it be buying a product or bringing awareness to a problem. The ultimate goal of all advertising is the same to influence the behavior of the intended target consumers. While most people assume that advertising is about getting consumers to buy a certain product, there are many motivations behind advertising. Businesses and organizations will use advertising to influence the opinions of target audiences or raise awareness of certain issues. Just like different advertising objectives, they also vary in style and form. According to (Mnamara, 2021), advertising brings a product or service to the attention of potential customers and current customers. Advertising is focused on one particular product or service. Thus, an advertising plan for one product may be very different from a plan for another. Advertising is usually done with signs, brochures, advertisements, direct mail or email messages, personal contacts, and others.

According to (Enehasse and Saglam, 2020), research results show that digital media advertising has important and beneficial outcomes on consumer behavior. Also, brand trust moderates the relationship between digital media marketing and consumer behavior. According to (Park and Nicolan, 2015), reflects the way people make decisions: deciding whether to visit an area or not, whether to buy products advertised in the area, and whether to buy products together or individually in the area. Empirical analysis, applied to a sample of 11,288 individuals, shows that advertising influences positively on consumers' purchasing decisions to visit and purchase products and services.

H1: There is an effect of advertising on consumers' purchasing decision.

Direct Marketing. According to (Srinivasan, 2021), direct marketing is a marketing strategy in which target customers are contacted directly and eliminates the need for intermediaries such as retailers. Results from direct marketing campaigns are immediately measurable because your business can track how many customers respond positively. Direct marketing largely relies on individual distribution of sales promotions to consumers and their potential customers, personally. The types of direct marketing consist of: face-to-face marketing, door-to-door marketing is another form of face-to-face marketing, brochures, telemarketing, email marketing, targeted advertising and coupons. The advantage of Direct Marketing is to build better relationships with returning customers and new customers by contacting them directly, testing the attractiveness of products and services and getting direct feedback from the target audience and improving the products and services offered, understanding which marketing techniques can work, be a better way to reach the target audience directly for business, provide customers with any interesting content that they can share with other potential customers and provide a positive boost in sales by gaining loyal customers. 
According to (Kononenko, 2021), direct marketing is a type of promotion that offers the transfer of information about a product, service or company directly to a client. Thus, the target audience receives all advertising information without intermediaries and third parties. Direct marketing methods can serve two purposes: the development of strong relationships with buyers and actual sales. The most popular type of direct marketing is that email notifications are a simple, affordable and scalable way to communicate with customers. This mobile marketing is considered to be four and five times more effective than other forms of online advertising. This is based on sending promotional materials to your mobile device. There is no need to collect email addresses or other personal data because customers are identified by the information stored in the browser used.

According to (Paludi et al., 2018), companies should hire train and motivate their sales force. He must create a communication and promotion program consisting of advertising, sales promotion, public relations and direct and online marketing. Thus, good communication is expected to be able to influence consumer attitudes and behavior to make ticket purchasing decisions at PT PELNI. According to (Aini and Hasmin, 2015), sales activities are only limited to customers who come directly to travel and buy tickets, as a result marketing activities are limited because they are only able to reach people around the area or city where the travel is located. Another problem is that providing information to customers is still through banners and brochures. Starting from the problems above, it is considered necessary to have an e-commerce application that can provide convenience for agents. In the development of the Pelni ship ticket ordering application, a client server architecture is used by utilizing the internet network as the media network, and the Android application on the client side and the server side is built on a web-based basis. In communicating between two different platforms, an interface is needed to connect the two platforms above, so JavaScript Object Notation (JSON) is used as the interface between the Android cilet and the web server. The results of this study are in the form of a mobile application that can be used to make Pelni ship ticket reservations on Fathir Almur travel so that customers do not need to go to the ticket agent office to purchase Pelni ship tickets.

H2: There is a direct marketing effect on consumer purchasing decision.

Word of Mouth. As reported by (Pate, 2021), word of mouth marketing is a strategy that relies on customers' experiences with certain brands and recommendations they share with their friends and family. It is a form of free advertising that is triggered by the impressions, feelings, and thoughts of the buyer. When the Internet is filled with various marketing techniques, it can be difficult to find a brand that is promoted organically. However, the easiest way to achieve this is to treat customers well, ensure the quality of the product or service and continue to do their best. Nielsen reports that 83 percentage of customers who participated in its survey trust companies that their family and friends recommend. Other people's experiences with certain brands are often a source of information for many consumers because they are more relatable and trustworthy. Every customer can be a part of word of mouth promotion in various ways. It could be a video on Instagram Stories, a review on a website, a hashtag, or a tag. Satisfied consumers with a product can easily popularize the company and help it earn more profits. First, the strategy doesn't always cost extra and helps reach new clients who will be loyal to your company. Second, 
recommendations from friends and family always drive interest and trust in a particular brand. This is an opportunity to build your image as a credible, reliable and trustworthy brand. Companies that implement word of mouth get increased conversions, higher sales, and wider reach. All these factors create a great incentive for higher profits. The more people learn about your brand, whether from friends' posts or direct recommendations, the higher your brand awareness and likelihood of brand engagement.

As reported by (Tsai and Bui, 2021), structural equation modeling reveals that WOM of social media users significantly influences consumers' purchase intentions. That is, WOM increases the benefits of social media sources of information about cruise ship travel. Furthermore, sharing experiences through WOM significantly impacts consumer decision making. The development of information technology has brought changes to the development of the business world, and is widely used by business people to compete in their marketing activities. Therefore, marketing activities are increasingly broad and complex. Currently, consumers are increasingly easy to exchange information with other consumers in choosing the products they will buy.

H3: Word of Mouth (WOM) communication is important in marketing, because it can affect.

Personal Selling. In accordance with (Hudson and Hudson, 2017), personal selling is a personalized form of communication in which a seller presents product features and benefits to a buyer for the purpose of making a sale. The high level of personalization involving personal selling usually comes at a much greater cost per contact than mass communication techniques. The marketer must decide whether this additional cost is justified, or whether the marketing objectives can be achieved by communicating with potential customers in the group. Some tourism and hospitality organizations prefer private selling over others, for them the potential benefits outweigh the additional costs. Personal selling plays a number of important roles in the tourism and hospitality industry including: gathering marketing intelligence, finding and retaining customers, promoting at travel fairs, generating sales at the point of purchase, using relationship marketing, providing detailed and up-to-date information for travel fairs.

In accordance with (Prasetyo and Ridwanudin, 2016), the results of the study show that there is a significant influence between personal sales activities on purchasing decisions to make a visit to the Jendela Alam tourist attraction in the city of Bandung. In accordance with (Aprianto and Candraningrum, 2020), the results of the correlation coefficient test explain that there is a strong relationship between personal selling and buying interest variables. Meanwhile, the dimensions that support the effectiveness of personal selling include the ability to approach, presentation, overcoming objections, and closing. The ability to open communication, present products and be able to answer questions from potential customers.

H4: There is an influence of personal selling on consumer purchase decision.

Consumer Purchase Decisions. As stated by (Lucid Content Team, 2021), the five step consumer decision-making process consists of: problem recognition, Recognizing the need 
for a service or product, information seeking: Gathering information, evaluating alternatives: Weighing options against comparable alternatives, purchasing decisions: Making the actual purchase and post-purchase evaluation. In the consumer decision-making process, potential buyers have developed criteria for what they want in a product. They are now weighing their prospective options against comparable alternatives. Alternatives can appear in the form of lower prices, additional product benefits, product availability, or something personal like color or style choices. Convince consumers that your product is superior to other alternatives. Purchasing decisions are made after gathering all the facts, including feedback from previous customers. The consumer must come to a logical conclusion about the product or service to buy.

As stated by (Milwood, 2021), the consumer decision-making process is the process by which consumers become aware of and identify their needs; gather information on how best to address these needs; evaluate the available alternative options; make purchasing decisions; and evaluate their purchases. The consumer decision-making process consists of: need recognition (awareness) information seeking (research): evaluation of alternatives (consideration) comparing options to make the best choice, purchasing decisions (conversion) of buying behavior into action and post-purchase evaluation (re-purchase).

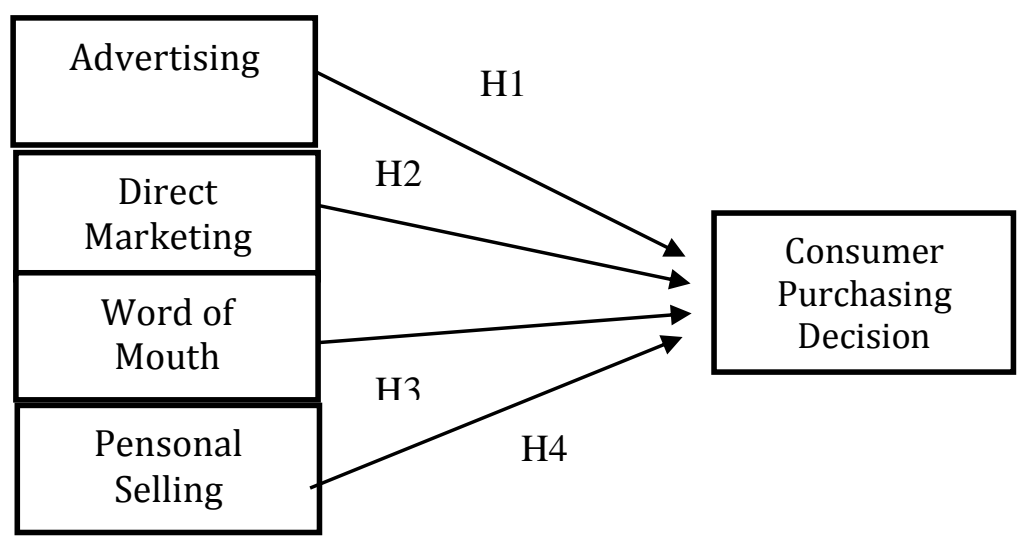

Figure 1. Research Model

\section{METHOD}

The indicators used to measure advertising according to (Hawks, 2021), (Goorevich, 2019) and (McNamara, 2021) consist of: announcing or providing information (to inform), to persuade), influence consumers to buy, and remind. An example is an advertisement for passenger ships in Tanjung Pasir providing information on departure and arrival schedules. The passenger boat advertisement in Tanjung Pasir influenced my decision to buy a ticket.

The indicators used to measure direct marketing according to (Srinivasan, 2021) consist of face-to-face marketing, door-to-door marketing, telemarketing, and email marketing. An example is a marketer directly marketing passenger ship tickets to consumers 
in Tanjung Pasir. Information on ticket prices and departure and arrival schedules for passenger ships in Tanjung Pasir is sent by marketing to consumer emails.

The indicators used to measure word of mouth according to (Pate, 2021), (Glover, 2021) consist of: recommending the company's products or services to family and friends, supporting family and friends to buy the company's products or services, telling the company's products and services to others. family and friends. Examples of getting information on the departure and arrival schedules of passenger ships in Tanjung Pasir from family and friends, Persuading family and friends to use passenger ships in Tanjung Pasir.

The indicators used to measure personal selling according to (Hudson and Hudson, 2017), (Prasetyo and Ridwanudin, 2016) consist of: presenting the features and benefits of products and services to consumers, finding and retaining consumers, identifying consumers, approachability, product presentation, the ability to answer consumer questions, Examples are salespeople are able to answer consumer complaints, salespeople take a friendly approach to consumers about ordering passenger boat tickets in Tanjung Pasir.

The indicators used to measure consumer purchasing decisions according to (Mrinalini, 2021) and (Lucid Content Team, 2021) consist of: problem recognition, recognizing the need for services or products, information seeking, alternative evaluation, decision making and post-purchase evaluation. For example, I bought a ticket because the ticket price was affordable and the length of the passenger boat trip was faster, consumers were interested in buying passenger boat tickets after the salesperson offered convincingly.

Research design. The research design used is quantitative research with stages consisting of: problems, research objectives, theoretical basis and hypotheses, distributing questionnaires to respondents, data collection and analysis, research results and discussion, conclusions and managerial implications.

Population and Sample. The population is all tourists who depart from Tanjung Pasir Beach by motor boat to Untung Jawa Island and Rambut Island. The sample used was purposive sampling with questionnaires distributed to 156 respondents and 82 returning questionnaires, while the non-returning questionnaires amounted to 74 respondents. The questionnaire given to respondents who used the services of passenger ships during the 5 months of the study amounted to 156 respondents. However, the returned questionnaires and complete answers amounted to 82 respondents. The questionnaires that did not return were 74 respondents with the reasons that they were busy, did not want to be disturbed and did not want to give the right and correct answers. The research was conducted in Tanjung Pasir, Teluk Naga District, Tangerang Regency from May to November 2021.

Variable Measurement. Measurement of four independent variables consisting of advertising, direct marketing, word of mouth and personal selling and one variable, namely consumers' purchasing decision. The Likert scale used in the questionnaire instrument of this study was 1 means strongly disagree, 2 means disagree, 3 means sufficient, 4 means agree and 5 means strongly agree.

Analysis Techniques. The analytical technique used in this research is construct validity and reliability, outer loading, collinearity statistics, path coefficients, $\mathrm{R}$ square and model fit using SmartPLS software. 


\section{RESULTS}

The information obtained by the researcher is based on direct observation and several owners and sales force of Motor Ships, officers of the Tangerang Regency Transportation Service and the Thousand Islands Regency Transportation Office of DKI Jakarta that the average tourist who visits uses a motorboat from Tanjung Pasir to Untung Jawa Island in July to November 2021 numbered 14,000 people. Departures of tourists who come with friends or family visiting from Tanjung Pasir on Saturday and returning from Untung Jawa Island on Sunday. $11 \mathrm{KM}$ in Tanjung Pasir are Sinar Harapan, Arjuna, Bima Suci, Mawar Express, Village Girl, Mulyadi Jaya, Makmur Jaya, Cemara Jaya 2, Simponi 1, Cahaya Alam and Sri Ulah.

Based on table 1, it was found that male respondents were 39.02percentage and female respondents were 60.98 percentage. Percentage of age 17 to 44 years is 46.34 percentage less than 17 years is 39.02 percentage and over 45 years is 14.64 percentage. Education at the elementary, junior high and high school levels is 53.66 percentage, undergraduate school is 34.15 percentage and graduate school is 12.19 percentage. The respondent's place of residence in Jakarta is 41.46 percentage, Serang City and Regency is 18.29 percentage, Bogor City and Regency are 4.88 percentage, Tangerang City and Regency are 19.51 percentage, Bekasi City and Regency are 6.09 percentage and other cities and regencies 9.76 percentage. 23.17percentage work as government employees, 51.21percentage work as private employees and 25.61 percentage are still students. 9.76 percentage of respondents' income is less than 5 million, 47.56percentage of respondents' income is between 6 to 10 million, 42.68percentage of respondents' income is more than 10 million. 63.41 percentage of passenger ship information comes from families and 36.59percentage comes from travel and tour agents. 8.54percentage of passenger boat tickets were purchased for 1 person, 39.02percentage were purchased for 2 people and 52.44percentage were purchased for more than 3 people. 34.14 percentage passenger ship tickets for 1 day, 59.76percentage passenger boat tickets for 2 days and 6.10percentage passenger boat tickets for 3 days.

Table 1. Respondent Data

\begin{tabular}{l|c|c}
\hline \multicolumn{1}{c|}{ Description } & Frekuensi & Persentase \\
\hline Sex & 32 & \\
Male & 50 & 39,02 \\
\hline Female & 32 & 60,98 \\
\hline Age & 38 & 39,02 \\
Less Than 17 years & 12 & 46,34 \\
\hline 17 to 44 years & & 14,64 \\
\hline Greater than 45 years & 44 & 53,66 \\
\hline Education & 28 & 12,20 \\
Eelementary School, Junior and Senior High School & 10 & 12,95 \\
\hline Under Graduate School & & \\
\hline Graduate School & 34 & 41,46 \\
\hline Residences & 15 & 19,30 \\
\hline Jakarta Metropolitan & 4 & 4,89 \\
\hline City and Municipality of Serang & & \\
\hline City and Municipality of Bogor & &
\end{tabular}




\begin{tabular}{l|c|c}
\hline City and Municiaplity of Tangerang & 16 & 19,51 \\
\hline City and Municiaplity of Bekasi & 5 & 6,10 \\
\hline Others Cities and Municipalities & 8 & 12,20 \\
\hline Occupation & 19 & 23,17 \\
Public Employees & 42 & 51,21 \\
\hline Private Enployees & 21 & 14,62 \\
\hline Students & & 9,76 \\
Income per Month & 39 & 37,89 \\
\hline Less Than 5 million & 35 & 47.55 \\
\hline 6 to 10 million & 52 & 63,41 \\
\hline Greater Than 10 million & 30 & 36,59 \\
\hline Passenger ship information Comes From & & 8,54 \\
Family & 7 & 39,02 \\
\hline Tours and Travel Agency & 32 & 52,44 \\
\hline Purchase of Passenger ship Tickets & 43 & \\
1 person & & 34,14 \\
\hline 2 person & 28 & 59,76 \\
\hline More Than 3 person & 49 & 6,10 \\
\hline how many days by passenger ship & 5 & \\
\hline 1 day & & \\
\hline 2days & & \\
\hline 3 days & & \\
\hline Sour Data Processed by Research & & \\
\hline
\end{tabular}

Source: Data Processed by Researchers

Construct Reliability and Validity. Table 2 data shows that convergent validity is used to prove the questionnaire items on each exogenous latent variable of product quality and service quality as well as endogenous variables of customer satisfaction and customer loyalty. Construct reliability and validity using Cronbach's alpha, rho_A, composite reliability and average variance extracted analysis. Cronbach's alpha value greater than 0.600 can be said to be acceptable, reliable or consistent. The value of rho_A greater than 0.600 can be said to be acceptable, reliable or consistent. The composite reliability value greater than 0.600 can be said to be acceptable, reliable or consistent. Based on table 3, discriminant validity is used to prove that the questionnaire items are valid or invalid. The average variance extracted and discriminant validity greater than 0.500 can be said to be valid or acceptable.

Table 2. Construct Reliability and Validity

\begin{tabular}{l|l|l|l|l}
\hline & Crombach's Alpha & Rho_A & $\begin{array}{l}\text { Composite } \\
\text { Reliability }\end{array}$ & $\begin{array}{l}\text { Average } \\
\text { Extracted }\end{array}$ \\
\hline $\begin{array}{l}\text { Consumers' } \\
\text { Purchase Decision }\end{array}$ & 0,814 & 0,814 & 0,878 & 0,643 \\
\hline Direct Marketing & 0,647 & 0,745 & 0,777 & 0.574 \\
\hline Personal Selling & 0,656 & 0,699 & 0,702 & 0,503 \\
\hline Advertising & 0,808 & 0,932 & 0.856 & 0,607 \\
\hline Word of Mouth & 0,880 & 0,913 & 0,917 & 0,735 \\
\hline
\end{tabular}

Source: Data Collected and Processed with SmartPLS Software

Table 3 data on the outer loading test shows that the loading factor value of the latent variable of advertising, personal sales, consumer purchasing decisions, direct marketing and 
word of mouth greater than 0.600 can be said to be valid or acceptable.

Table 3. Outer Loading

\begin{tabular}{l|l|l|l|l|l}
\hline & Advertising & Personal Selling & $\begin{array}{l}\text { Consumers' } \\
\text { Purchasing } \\
\text { Decision }\end{array}$ & $\begin{array}{l}\text { Direct } \\
\text { Marketing }\end{array}$ & $\begin{array}{l}\text { Word of } \\
\text { Mouth }\end{array}$ \\
\hline 1 & 0.657 & 0.667 & 0.853 & 0.684 & 0,782 \\
\hline 2 & 0.887 & 0,637 & 0.768 & 0.667 & 0,840 \\
\hline 4 & 0.933 & 0,773 & 0,820 & 0.898 & 0,923 \\
\hline
\end{tabular}

Source: Data Collected and Processed with SmartPLS Software

Based on table 4. Collinearity Statistics below, it shows that all indicators of latent variables of advertising, personal sales, consumer purchasing decisions, direct marketing and word of mouth have a VIF value less than 5 so that all indicators do not experience multicollinearity problems. If there is a VIF indicator value greater than 5 then there is a multicollinearity problem. The consequence is that dropping or removing one of the indicators that are strongly correlated can be done.

Table 4. Collinearity Statistics (VIF)

\begin{tabular}{l|l|l|l|l|l}
\hline & Advertising & Personal Selling & $\begin{array}{l}\text { Consumers' } \\
\text { Purchasing } \\
\text { Decision }\end{array}$ & $\begin{array}{l}\text { Direct } \\
\text { Marketing }\end{array}$ & $\begin{array}{l}\text { Word of } \\
\text { Mouth }\end{array}$ \\
\hline 1 & 2.369 & 1.003 & 2.568 & 1.429 & 1,815 \\
\hline 2 & 2.590 & 1,020 & 2.175 & 1.427 & 2,280 \\
\hline 4 & 2.986 & 2,567 & 1.940 & 1.637 & 3,200 \\
\hline
\end{tabular}

Source: Data Collected and Processed with SmartPLS Software

Path Coefficients. In table 5 and figure 2 it is recorded that the first hypothesis is the tcount value of 2.185 greater than than the t-table of 1.991 and a significant value of 0.033 less than 0.05 , it can be interpreted that advertising has a significant influence on consumer purchasing decision. The second hypothesis is that the $\mathrm{t}$-count value is 2.145 greater than from the t-table 1.991 and the significant value is 0.035 less than 0.05 , it can be interpreted that direct marketing has a significant influence consumer purchasing decision. The third hypothesis is the t-count value of 3.055 greater than from the t-table of 1.991 and a significant value of 0.022 less than 0.05 , it can be interpreted that word of mouth have a significant influence on consumer purchasing decision. The fourth hypothesis is that the $\mathrm{t}-$ count value is 4.281 greater than from the t-table 1.991 and the significant value is 0.000 less than 0.05 , it can be interpreted that personal selling have a significant influence on consumer purchasing decision. 
Table 5. Path Coefficients

\begin{tabular}{l|l|l}
\hline & T & P \\
& Statistic & Values \\
\hline Direct Marketing & 2,145 & 0.035 \\
\hline Personal Selling & 4,281 & 0,000 \\
\hline Advertising & 2,185 & 0,033 \\
\hline Word of Mouth & 3,055 & 0,022 \\
\hline
\end{tabular}

Source: Data Collected and Proccessed with SmartPLS Software

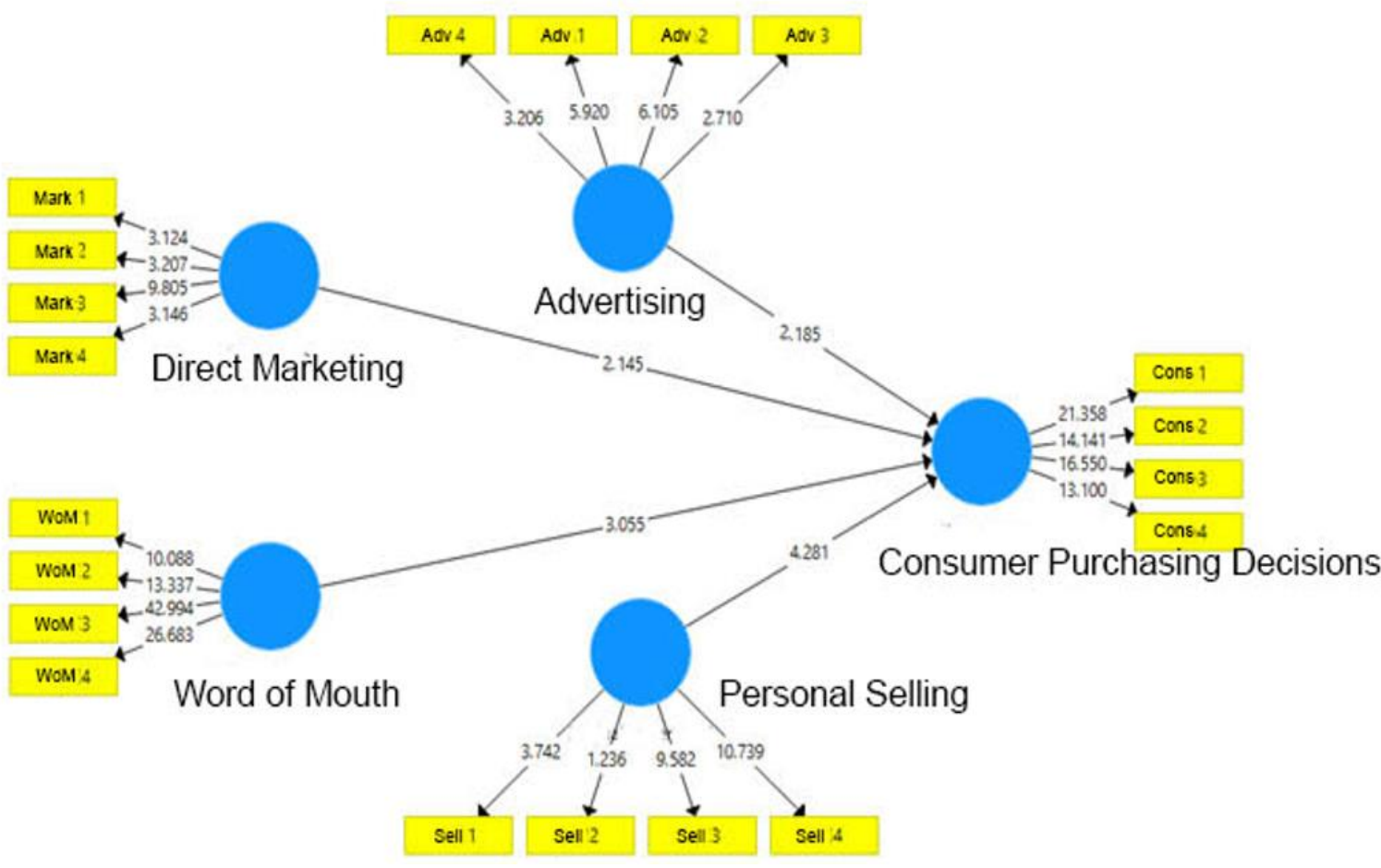

Figure 2. $\mathrm{T}$ Values

R Square. In table 6 it is noted that the $\mathrm{R}$ square value of 0.508 means that advertising, direct marketing, word of mouth and personal selling have an influence on consumer purchasing decisions by 50.80 percentage and 49.20 percentage is influenced by other variables.

Tabel 6. $R$ Square and $R$ Square Adjusted

\begin{tabular}{l|l|l}
\hline & $R$ Square & $R$ Square Adjusted \\
\hline Consumer Purchasing Decision & 0,508 & 0,482 \\
\hline
\end{tabular}

Source: Data Collected and Proccessed with SmartPLS Software 
Model Fit. Model fit can be measured in several ways such as SRMR, d_ULS, d_G, Chi Square and NFI. The Standardized Root Mean Square (SRMS) value of 0,077 can be said that the model fit between the observed correlations or relationships is quite good. The value of d_ULS (the Square Euclidean Distance) of 3,382 and d_G (the Geodesic Distance) of 1.215 can be said to meet the criteria for a fairly good node fit. The Chi Square value of 584,953 can be said to meet the criteria of very good model fit. The Normed Fit Index (NFI) has a statistical value of 0.491 , so this shows that it is quite good to meet the criteria of the fit model.

Tabel 7. Model Fit

\begin{tabular}{l|l|l}
\hline & \multicolumn{1}{|c}{ Saturated Model } & \multicolumn{1}{c}{ Estimated Model } \\
\hline SRMR & 0,077 & 0,077 \\
\hline d_ULS & 3,382 & 3,382 \\
\hline d_G & 1,215 & 1,215 \\
\hline Chi Square & 584.953 & 584.953 \\
\hline NFI & 0.491 & 0.491 \\
\hline \multicolumn{2}{l}{ Source: Data Collected and Proccessed with SmartPLS Software }
\end{tabular}

\section{DISCUSSION}

The first hypothesis can be interpreted that advertising has a significant influence on consumer purchasing decisions. The more advertising that is delivered to the customer, the higher the consumer's purchase decision. The dominant advertising indicator is announcing or providing information to family and friends compared to other indicators to persuade, influence consumers to buy, and remind. This study is in accordance with previous research conducted by (Shubhangam et al., 2020), the results show that social media advertising significantly influences purchasing decisions or buying interest and brand loyalty. This also shows that the purchase decision or purchase intention of the customer affects brand loyalty. This research is also agreed by previous research conducted by (Saputra et al., 2018) that informative traveloka advertising on television has a positive and significant effect on buying interest or purchasing decisions for airline tickets in the Samarinda backpacker community. Traveloka advertisements on television affect buying interest or purchasing decisions for airplane tickets in the Samarinda Backpacker community by 44.2 percentage.

The second hypothesis can be interpreted that direct marketing has a significant influence on consumer purchase satisfaction. The more direct marketing carried out by the owners and sales force of the Tanjung Pasir motor boat, the more consumers' purchasing decisions using the Tanjung Pasir - Untung Jawa Island motor boat service will increase. Owners and sales force use telemarketing or remote marketing more to communicate with regular, non-permanent and new customers than direct mail, kiosks and travel and tourism agency websites. This research is in agreement with previous research conducted by (Rini et al., 2021) PT Warna Warni Media, as a company engaged in outdoor media advertising services and marketing its products directly. This company has two direct marketing channels in marketing the company's products, namely through face-to-face contact with Account Executives assisted by direct mail by Marketing Support. Over the past three months, the Direct Marketing Team has managed to reach an agreement 67 times out of 132 
negotiations that have been conducted. The success of a direct marketing company cannot be separated from the form of promotion it provides, in the form of discounts, barter and sponsorship programs so as to attract consumer purchasing decisions.

The third hypothesis can be interpreted that word of mouth has a significant influence on consumer purchasing decisions. The more owners and sales force of motorboats carry out word of mouth activities, the more tourists purchase decisions to buy motor boat tickets with the Tanjung Pasir - Untuing Island route, Java. An excellent indicator is recommending the experience of using a motor boat on the Tanjung Pasir - Pulau Untung Jawa route to friends and family rather than just providing information and feeling happy. This research is in line with previous research conducted by (World Tourism Cities Federation, 2018), Most Chinese tourists, especially the elderly, travel abroad with family or friends. When making decisions, 'word of mouth' has a significant influence on the Chinese language choice of outbound tourists' destinations. Due to cultural and language barriers, Chinese outbound tourists tend to travel in groups and have high expectations from tour guides

The fourth hypothesis can be interpreted that personal selling has a significant influence on consumer purchasing decisions. The more activities carried out by the owners and personal sales sales force to permanent, non-permanent and new customers, the higher the consumer purchasing decisions to buy motor boat tickets for the Tanjung Pasir - Untung Jawa route. The dominant indicator is the incentive program created by the owners and sales force of motor boats compared to sales presentations, sales meetings, san fairs and trade shows. This study agrees with previous research proposed by (Aji, 2015), the percentage of the contribution of the influence of the independent variable (personal selling) on the dependent variable (purchase decision) of 26.4 percentage or the variation of the independent variable used in the model (personal selling) is able to explain 26.4percentage of the variation in the dependent variable. This research is also in line with previous research conducted by (Rahim, 2017) advertising, public relations and direct sales have a simultaneous effect on the decision to visit the tourist attraction of Ladaya Kutai Kartanegara. Promotional mix variables which consist of advertising, public relations and direct sales have a partial effect on tourists' decisions to visit the tourist attraction of Ladaya Kutai Kartanegara.

\section{CONCLUSION}

Consumer purchasing decisions are significantly influenced by advertising. The more advertising that is delivered to the customer, the higher the consumer's purchase decision. Informative advertising indicators are more prominent than persuasive advertising, reminder advertising and reinforcement advertising. Consumer purchasing decisions are significantly influenced by direct marketing. The more direct marketing carried out by the owners and sales force of the Tanjung Pasir motor boat, the more consumers' purchasing decisions using the Tanjung Pasir - Untung Jawa Island motor boat service will increase. Owners and sales force use telemarketing or remote marketing more to communicate with regular, non-permanent and new customers than direct mail, kiosks and travel and tourism agency websites.

Consumer purchasing decisions are significantly influenced by word of mouth. The more owners and sales force of motorboats carry out word of mouth activities, the more 
tourists purchase decisions to buy motor boat tickets with the Tanjung Pasir - Untuing Island route, Java. An excellent indicator is recommending the experience of using a motor boat on the Tanjung Pasir - Pulau Untung Jawa route to friends and family rather than just providing information and feeling happy. Consumer purchasing decisions are significantly influenced by personal selling. The more activities carried out by the owners and direct sales sales force to permanent, non-permanent and new customers, the higher the consumer purchasing decisions to buy motor boat tickets for the Tanjung Pasir - Untung Jawa route. The dominant indicator is the incentive program created by the owners and sales force of motor boats compared to sales presentations, sales meetings, san fairs and trade shows. It can be concluded that consumer purchasing decisions are significantly influenced by advertising, direct marketing, word of mouth and personal selling.

Practical / Theoretical Implications. Based on the results of the research and the conclusions mentioned above, the managerial implications obtained are that the owners and sales force must continue to increase advertising along the road to Tanjung Pasir beach, direct marketing, word of mouth and personal selling in order to increase the number of customers, both permanent and non-permanent. And those who use the services of the Tanjung Pasir motor boat - Untung Jawa Island. The need for the DKI Jakarta Provincial Government to provide training on direct marketing advertising, word of mouth and personal selling to owners and sales force of motorboats on the Tanjung Pasir - Untung Jawa Island route. The limitations of this study are the small population and sample and only includes tourists who use ship transportation on Tanjung Pasir Beach and the research time is limited to 5 months. It is recommended to future researchers to use more samples so that the research results will be even better.

Limitations and Suggestions. The limitations of this study are the small population and sample and only covers DKI Jakarta City, Tangerang City and Regency and the research time is only 5 months. It is recommended to future researchers to use more samples and also more cities and other districts so that the research results will be better and precise.

\section{REFERENCES}

Aini, N., dan Hasmin, E. (2015). Pengembangan Aplikasi Pemesanan Tiket Pelni Berbasis Mobile. Prosoding Seminar Ilmiah Sistem Informasi Dan Teknologi Informasi, 4(2), 172-181.

Aji, A. B. B. (2015). Pengaruh Personal Selling Terhadap Minat Beli Produk Takaful Dana Pendidikan (Fulnadi) Asuransi Takaful Keluarga Cabang Bengkulu (Syakroni \& K. Elwardah (eds.); 1st ed.) [Institut Agama Islam Negeri Bengkulu]. http://repository.iainbengkulu.ac.id/id/eprint/85.

Aprianto, N., dan Candraningrum, D. A. (2020). Pengaruh Personal Selling terhadap Minat Beli Produk PRUlink Generasi Baru Nasabah Prudential Life Assurance Indonesia. Prologia, 3(2), 313-319. https://doi.org/10.24912/pr.v3i2.6348.

Balai Konservasi Sumber Daya Alam DKI Jakarta. (2021). Suaka Margasatwa Pulau Rambut. Balai Konservasi Sumber Daya Alam DKI Jakarta. https://bksdadki.com/page/kawasan_dki/Suaka-Margasatwa-Pulau-Rambut. 
Enehasse, A., and Sağlam, M. (2020). The Impact of Digital Media Advertising on Consumer Behavior Intention: The Moderating Role of Brand Trust. Journal of Marketing and Consumer Research, 68(June), 22-32. https://doi.org/10.7176/jmcr/68-04.

Glover, M. (2021). Word of Mouth Marketing in 2021: How to Create a Strategy for Social Media Buzz \& Skyrocket Referral Sales. Bigcommerce.

Goorevich, E. (2019). What Is Advertising and What Makes an Ad Successful. G2.

Haryanto, J., dan Yunita, A. (2012). Pengaruh Word of Mouth, Iklan Dan Atribut Produk Terhadap Keputusan Pembelian Dan Loyalitas Konsumen. Journal of Technology Management, 11(1), 75-95. https://media.neliti.com/media/publications/117007-IDpengaruh-word-of-mouth-iklan-dan-atribut.pdf.

Hawks, D. (2021). What is Advertising? - Definition \& Examples. Https://Study.Com.

Hudson, S., and Hudson, L. (2017). Marketing for Tourism, Hospitality \& Events (S. Hudson \& L. Hudson (eds.); 1st ed.). SAGE Publications Lt. https://uk.sagepub.com/en-gb/eur/marketing-for-tourism-hospitalityevents/book245924.

Kononenko, I. (2021). What is Direct Marketing: Definition, Types, Components, and Examples. Rgray.

Lucid Content Team. (2021). Definition and Examples of the Consumer Decision-Making Process. Lucid Content Team. https://www.lucidchart.com/blog/consumer-decisionmaking-process.

McNamara, C. (2021). Basic Definitions: Advertising, Marketing, Promotion, Public Relations and Publicity, and Sales. Https://Managementhelp.Org.

Millwood, A. (2021). Understanding the Consumer Decision Making Process. Yotpo. https://www.yotpo.com/resources/consumer-decision-making-process-ugc/.

Mrinalini L. (2021). Consumer Decision Making. Yourarticlelibrary.Com. https://www.yourarticlelibrary.com/consumer-behaviour/consumer-decisionmaking/99878.

Nielsen. (2012). Consumer Trust in Online, Social and Mobile Advertising Grows. Nielsen.

Paludi, S., Raharjo, P. G., \& Sholekhah, E. S. (2018). Pengaruh Harga Promosi dan Kualitas Layanan Terhadap Kepuasan Pelanggan KM Dorolonda PT Pelni (Jakarta-Makassar). Jurnal Eduturisma, 4(2), 35-56. https://ejournal.akpindo.ac.id/index.php/eduturisma/article/view/1199.

Park, S., and Nicolau, J. L. (2015). Differentiated Effect of Advertising: Consumption, Joint Vs Separate. Elsevier in Tourism Management, 47, 107-114. https://doi.org/http://dx.doi.org/10/1016/j.tourism.2014.09.018.

Pate, N. (2021). What is Word-of-Mouth Marketing: Basics. Sendpulse.

Prasetyo, A. A., dan Ridwanudin, O. (2016). Pengaruh Personal Selling Terhadap Keputusan Berkunjung di Jendela Alam. THE Journal: Tourism and Hospitality Essentials Journal, 6(2), 1077. https://doi.org/10.17509/thej.v6i2.5518.

Rahim, R. (2017). Pengaruh Bauran Promosi Terhadap Keputusan Wisatawan untuk Berkunjung ke Daya Tarik Wisata Ladaya Kutai Kartanegara. Jurnal Administrasi Bisnis, 5(1), 13-25. https://ejournal.hi.fisip-unmul.ac.id/site/wpcontent/uploads/2017/02/Jurnal Ria Rahim (02-23-17-04-45-13).pdf.

Rini, R. S., Roni, F., dan Maharani, B. P. (2021). Saluran Pemasaran Langsung Jasa 
Periklanan Media Luar Ruang Pt Warna Warni Media. Scietific Journal of Reflection, 4(1), 101-110. https://doi.org/https://doi.org/10.37481/sjr.v4i1.252.

Saputra, A. W., Fourqoniah, F., dan Hairunnisa. (2018). Pengaruh Iklan Traveloka di Televisi Terhadap Minat Beli Tiket Pesawat Komunitas Samarinda Backpacker. EJournal Ilmu Komunikasi, 6(3), 250-262. https://ejournal.ilkom.fisipunmul.ac.id/site/wp-content/uploads/2018/08/JURNAL Pdf (08-13-18-02-5556).pdf.

Setyowahyudi, R. (2018). Pengaruh Iklan , Personal Selling dan Word of Mouth Terhadap Keputusan Pembelian Sepeda Motor Yamaha Nmax di Kabupaten Nganjuk. Jurnal Simki Economic, 02(03), 1-14. http://simki.unpkediri.ac.id/detail/13.1.02.02.0464.

Shubhangam, K., Srivastava, M., Ravi, R., and Singh, R. (2020). Influence of Social Media Advertisement on Customer'S Purchase Decision: A Literature Review. International Journal on Recent Trends in Business and Tourism, 4(October), 25-31.

Srinivasan, S. (2021). Direct Marketing: Definition, Types, Strategies \& Examples. Https://Www.Feedough.Com.

Tsai, F. M., and Bui, T. D. (2021). Impact of Word of Mouth via Social Media on Consumer Intention to Purchase Cruise Travel Products. Maritime Policy and Management, 48(2), 167-183. https://doi.org/10.1080/03088839.2020.1735655.

World Tourism Cities Federation. (2018). Market Research Report on Chinese Outbound Tourist (City) Consumption (2017-2018). http://oldwww.wtcf.org.cn/uploadfile/2018/0913/20180913025210427.pdf. 